\title{
"Music is an A-Political Subject": North American Musicologists in the Soviet Union, 1960s-1970s
}

\author{
OLGA PANTELEEVA
}

\begin{abstract}
The article details experiences of the US musicologists who applied for the travel grant that was established in the wake of the Lacy-Zarubin agreement (1958). Highly competitive, these grants propelled the careers of the future trend-setters in Russian and Soviet music studies, including Malcolm Hamrick Brown, Laurel Fay, and Richard Taruskin. The funded research topics reflected what was seen as respectable musicological scholarship in the 1960s United States. Contrary to later musicological trends, the selected proposals avoided political subject matter altogether. First, the article analyzes how Cold War politics were manifested through biopolitics. Those who went on exchange were to function as "sources of unbiased information" for Soviet citizenry about the "American way of life" - a concept that was raced, gendered, and conformed to strict standards of sexuality, ability, and mental health. The second half of the article deals with the lens through which the American musicologists perceived the disciplines of music history and theory in the Soviet Union, as well as personal connections resulting from the exchange program. Results of such exposure would come to fruition during the 1980s and 1990s, when the former exchange participants put forth less othering, less Cold-War-prone approaches to Soviet music.
\end{abstract}

The apartment I'm in is sort of the local "night club." Starting about 9 pm, the crowd begins to assemble around the miniature pool table in the kitchen. When 9 or more get in, an involuntary limit prevents others from entering, so now that I've conned the other Americans at the [Moscow State University] out of one of the two Embassy record players, the remaining crowd settles in the main bedroom to play and re-play the only two jazz records I have. ... My roommates have spared me no scorn for not bringing good jazz records along. I asked Mr. Catherman ... to please order some Oscar Peterson, Errol Garner, Dave Brubeck, Modern Jazz Quartet, etc., the next time he has some spare cash in the kitty. ${ }^{1}$

The resident of the "night club" apartment was Malcolm Hamrick Brown, then thirty-two years of age. One of the first American musicologists to go on an exchange program to the Soviet Union during the Thaw, Brown sent many such jovial missives from his dorm at the Moscow State Conservatory.

Brown's research trip was made possible by the Lacy-Zarubin agreement. Signed in Washington, DC, on January 27, 1958 and officially titled "Agreement Between the United States of America and the Union of Soviet Socialist Republics on Exchanges in the Cultural, Technical and Educational Fields," it was the result of negotiations between William Lacy, President Eisenhower's special assistant on EastWest exchanges, and Georgy Zarubin, Soviet ambassador to the United States. Educational exchanges were only a small part of the agreement that enabled cooperation in sports, tourism, radio and television,

\footnotetext{
${ }^{1}$ RC 218, folder 27, Brown, Malcolm H. (1961-1962), International Research and Exchanges Board Records, Manuscript Division, Library of Congress, Washington, DC (hereafter, IREX Records).
} 
air travel, and other areas. ${ }^{2}$ Performance exchanges, such as the Bolshoi Ballet tour in the United States in 1959, were carried out under the aegis of the same agreement.

Educational exchanges were administered by the "awkwardly named" Inter-University Committee on Travel Grants (IUCTG)_-“a nondescript label that would not raise suspicions,” as David Engerman puts it - that was based at Indiana University in Bloomington. ${ }^{3}$ Funding came from the member universities, as well as from the State Department's Bureau of Educational and Cultural Affairs. The agreement successfully weathered all the vicissitudes of the Cold War, including the Cuban Missile Crisis of 1962. In 1968, the International Research and Exchanges Board (IREX) took over and oversaw the program until 1991.

The Graduate Student and Young Faculty Exchange Program was the one under which Malcolm Brown and most other musicologists would travel to Moscow. This program allowed American graduate students working on their dissertations to spend one semester or a year at a Soviet institution of higher education in an official capacity as exchange students, with access to Soviet advisors as well as libraries and archives. The applicants were subjected to "name-checks" by the State Department that screened for "political maturity and emotional stability" and to determine if they were "steeped in the American tradition." Once the successful applicants were selected by the American side, they still had to be accepted by Soviet institutions-specifically by the Academy of Sciences or, more frequently, by the Ministry of Higher Education, since graduate students were the primary demographics of the exchange programs.

In the early years of the agreement, most of the Soviet students who went to the United States specialized in science and technology. On the American side, however, the number of students applying from the humanities was much greater. This was probably due to the fact that the Lacy-Zarubin agreement had strong backing from Slavic studies programs at American universities. Lacy and Zarubin agreed to start out with twenty students on each side for the academic year 1958-59. Already the second group the following year included a student of music-composer Stanley Krebs, who would soon publish the book Soviet Composers and the Development of Soviet Music, based on his experience at the Moscow Conservatory. ${ }^{5}$ Unlike the Americans, who evidently placed at least some value on musicology as a vehicle for cultural diplomacy, the Soviets did not send a single participant from a music-related field for the entire duration of the exchange program. An additional hindrance was the fact that musicology was studied in the conservatories in the USSR, while the exchange program operated at universities in the United States.

All in all, some sixty American participants from areas designated as Music, Musicology, and Ethnomusicology applied for the exchange program over the course of the 1960s and 1970s. Only about a third of them were awarded a fellowship. Highly competitive, the travel grant was a great facilitator of research careers. The names of rejected applicants are mostly obscure. The names of those who did go to the Soviet Union, on the other hand, include Laurel Fay, Theodore Levin, Richard Taruskin, and other future trend-setters in Russian and Soviet music studies.

\footnotetext{
${ }^{2}$ See "Text of Lacy-Zaroubin Agreement, January 27, 1958," https://librariesandcoldwarculturalexchange.wordpress.com/text-of-lacy-zaroubin-agreement-january-27-1958 (accessed September 10, 2019).

${ }^{3}$ David C. Engerman, Know Your Enemy: The Rise and Fall of America's Soviet Experts (New York: Oxford University Press, 2009), 87.

${ }^{4}$ Ibid., 90.

${ }^{5}$ Stanley D. Krebs, Soviet Composers and the Development of Soviet Music (New York: W. W. Norton, 1970).
} 
This essay analyzes experiences of musicologists who applied to the IUCTG and IREX grants and tracks the exposure to the Soviet life of those successful applicants who got to report back from the Soviet Union to the State Department. ${ }^{6}$ Contrary to the popular view of Soviet music studies as a politicized field, I first show that research topics were intentionally formulated as apolitically as possible, lest the Soviet side be offended by overt ideological differences. Next, I examine the dual role the exchangees were to play as both model representatives of the US democracy (with the attendant requirements to their gender, race, sexuality, and physical and mental health), and at the same time, semi-informal reconnaissance agents. Finally, I argue that personal contacts and divergent experiences gained by American musicologists behind the Iron Curtain during the 1960s-1970s were a key precondition for the 1980s-1990s paradigm shift in Russian music studies-away from the Cold War mentality.

\section{Objectives of the Exchange Program}

A National Security memorandum stated the objective of the exchange program as follows:

to promote within Soviet Russia an evolution toward a regime which will abandon predatory policies, which will seek to promote the aspirations of the Russian people rather than the global ambitions of International Communism, and which will increasingly rest upon the consent of the governed rather than on despotic police force. ${ }^{7}$

This objective, however, was not immediately apparent to United States citizens. When the news of the agreement and ensuing cultural exchanges reached the American public, it elicited "a great deal of resentment towards the United States Department of State." ${ }^{8}$ On February 9, 1959, retired colonel William B. Brown of Washington, DC, wrote in a letter addressed directly to Ambassador William Lacy that he found “'all kinds' of Red Propaganda bound in very attractive poison leaves" in a New York bookstore. He pointedly asked why this "scurrilous filth" that was "pushing the comic strips off the shelves" was allowed into the country, and demanded to know what kind of literature was sent in response to "Russia and other 'slave' countries." Mabel Ann Kelley of Sioux City, Iowa, inquired to whom she should write "in an effort to get reconsideration of this dangerous deal with Russia." ${ }^{10}$ A concerned constituent from California wrote to his representative, protesting the "Communist programs and movies that our State Department has forced upon us!" accidentally seeing them. Such responses were not at all surprising, considering that the signing of the agreement coincided with the tail end of McCarthyism. Some correspondents, however, supported the idea of the exchange precisely because they saw it as a useful way to win over the minds and hearts of Soviet citizens. For example, a dentist, Robert Bowen, wrote directly to President Eisenhower even before the Lacy-Zarubin agreement became a reality:

\footnotetext{
${ }^{6}$ There were many successful applicants who went on exchange programs to other countries of the Soviet bloc. However, in this article I will confine the discussion to the files of those who went to the Soviet Union.

${ }^{7}$ Norman E. Saul, "The Program that Shattered the Iron Curtain: the Lacy-Zarubin (Eisenhower-Khrushchev) Agreement of January 1958," in New Perspectives on Russian-American Relations, ed. William Benton Whisenhunt and Norman E. Saul (New York: Routledge, 2016), 230, https://doi.org/10.4324/9781315689777-17.

${ }^{8}$ Albion W. Johnson to DOS, Central Decimal File 1955-59 (hereafter CDF55-59) 511.61/2-1359, Record Group 59 (RG 59), National Archives at College Park (hereafter NA).

${ }^{9}$ Walter B. Brown to William S. B. Lacy, CDF55-59, 511.61/2-1059, NA.

${ }^{10}$ Mabel Ann Kelley to Charles B. Hoeven, CDF55-59, 511.61/2-2659, NA.

${ }^{11}$ Clem Miller to Lawrence Mitchell, CDF55-59, 511.61/2-1059, NA.
} 
The void between the thinking of Americans and the people of the USSR is so great because of the intolerable Communism of life, property and religion. I feel that military and economic pressure cannot be continued forever, therefore we should attempt to rectify the thinking in the Russian mind. ${ }^{12}$

The State Department's standard reply to these sorts of letters included a copy of the agreement and rehearsed the idea that the agreement's purpose was, in fact, to counteract the already existing Soviet propaganda in the United States. The United States was a democracy and did not censor any political positions, the argument went on. Therefore, because as long as there was demand for information about the Soviet Union, there would be supply of such information, it was therefore better to controlthrough the agreement-what kind of information entered the country. ${ }^{13}$ According to this logic, unofficial imports would have to compete with those movies and literature that were entering the country officially and were approved by the state. Furthermore, the agreement would allow the State Department to send the Soviet Union sources of "unbiased ... information about the United States," such as the journal America Illustrated. ${ }^{14}$

\section{"Music is an A-Political Subject"}

Insofar as music was considered an apolitical field, musicologists were ideal "sources of unbiased information" about the United States for the Soviet people. This idea also allowed music scholars to position themselves as low-risk visitors. "I do not foresee any risk to myself or to others which might result from a year's stay in the Soviet Union. Music is an a-political subject and I certainly do not intend to make it otherwise," 15 wrote Larry Snyder, a graduate student in musicology at UC Berkeley who proposed a (rejected) project on early Russian opera. Perhaps most importantly, state officials also saw the field of musicology as innocuous. For instance, musicologist Robert Sterling Beckwith went on exchange in 1963, but when he was applying again - for an exchange program for senior scholars in 1975-his application was refused. A State Department official in Moscow, one William Pryce, reported a conversation with the Soviet officials about the reason for Beckwith's rejection. According to the Soviets, a probable reason for the rejection was that the Ministry of Education was "unhappy with his activities during and the results of his earlier research visit to the USSR. Danilin at this point asked what Beckwith's field was and mumbled what could he have done that was unacceptable in a field like that." 16

The art of formulating a research topic acceptable to the Soviet side is well documented in literature on the exchanges. ${ }^{17}$ As Lewis Siegelbaum recalls, Soviet historiography tacitly shaped research questions asked by historians, who were "always conscious of the presence of [the Soviet] version" of the narrative. ${ }^{18}$ In the case of music, however, that meant reverting to the default idea that music was an apolitical art. This fact runs counter to what later became a mainstay of North American scholarship on Soviet music-the idea that the only issue that mattered in consideration of Soviet music was its

\footnotetext{
${ }^{12}$ Robert Bowen to President Dwight Eisenhower, CDF55-59, 511.61/7-2955, NA.

${ }^{13}$ William B. Macomber, Jr. to Charles B. Hoeven, CDF55-59, 511.61/2-2659, NA.

${ }^{14}$ William B. Macomber, Jr. to Walter B. Brown, CDF55-59, 511.61/2-959, NA.

${ }^{15}$ RC 075, folder 39, Snyder. Larry J. (1961-1962), IREX Records.

${ }^{16}$ RC 145, folder 18, Beckwith, Robert (1975-1976), IREX Records.

${ }^{17}$ For instance, see Sheila Fitzpatrick, A Spy in the Archives: A Memoir of Cold War Russia (London: I. B. Tauris, 2015), 116; Engerman, Know Your Enemy, 170.

${ }^{18}$ Lewis H. Siegelbaum, Stuck on Communism: Memoir of a Russian Historian (Ithaca, NY: Northern Illinois University Press, an imprint of Cornell University Press, 2019), 55, https://doi.org/10.7591/9781501747397.
} 
relationship with the state. ${ }^{19}$ The research topics sponsored by IUCTG reflected what in the 1960 s was seen as respectable musicological scholarship, both in the United States and in the Soviet Union. They comprised composers, genres, and masterpieces rather than the relationship between music and society. "A Study of Russian Symphonic and Chamber Literature of the Eighteenth Century" was the title of the proposal by Evangeline Vassiliades; ${ }^{20}$ Roland Wiley formulated his topic as "Tchaikovsky's Ballets: the history of Swan Lake, Sleeping Beauty, and Nutcracker, and their creators, based on surviving documents"; 21 Joel Spiegelman worked on "Russian Keyboard Music of the Eighteenth Century;"22 and Laurel Fay described her research project as "a detailed study and stylistic analysis of the string quartets of Alexander Glazunov, tracing their development from the earliest to latest." 23 Richard Taruskin, who would go on to become a foremost proponent of studying the political in music, also chose a topic that sounded neutral enough for the exchange: "The Problem of Realism in Russian Music," promising to "investigate the critical writings of V. V. Stasov, A. N. Serov, C. A. Cui, their predecessors and their successors and apply the insights I gain to an examination of representative works of leading Russian composers of their day in an effort to illuminate the relationship between the theory and the practice of nineteenth-century Russian musical esthetics." ${ }^{24}$ He admitted as much in his introduction to On Russian Music: "It was meant to appeal to the Soviet side, and it did." 25

Rejected topics provide more evidence that overtly political questions were unwelcome in research proposals. In 1976, Ellon Carpenter's proposal on the history of Soviet music theory asked the following questions: "How parallel is the development of Soviet theory to that in our own country? Are Soviet theorists concerned with the same topics in relation to their music as we are, or totally different ones? Does music theory contain an intrinsic integrity or a genetic development that is independent of any ideological position?”26 Her proposal was rejected. A violinist named Marlan Carlson, applying for an IUCTG grant in 1963, proposed a project titled: "Musical Programming in Leningrad-1910 to the present, relative to the historical setting." He wanted to work in the archives of the Leningrad Philharmonic Orchestra and the Leningrad Conservatory in order to consider the Leningrad concert life in a historical and political context. ${ }^{27}$ The committee took issue with the topic itself. Malcolm Brown assessed the proposal as "unimpressive. I question the value of the project as well as his qualifications to do a scholarly study." ${ }^{28}$ The interviewers gave two reasons for the rejection: "Instrumentalist. No good topic." ${ }^{29}$ Francis Tursi, a professor of viola at Eastman, wrote in his reference letter about the proposed project: "I personally question 1) its value and 2) its delicate and possibly offensive intent from the Russian viewpoint." ${ }^{30}$ Had this topic been accepted, Pauline Fairclough's recent monograph Classics for the Masses might have had a predecessor in the 1960s. In short, the IUCTG committee and the

\footnotetext{
${ }^{19}$ See Marina Frolova-Walker, “An Inclusive History for a Divided World?,” Fournal of the Royal Musical Association 143, no. 1 (2018): 1-20, https://doi.org/10.1080/02690403.2018.1434308.

${ }^{20}$ RC 121, folder 24, Vassiliades, Evangeline (1968-1969), IREX Records.

${ }^{21}$ RC 128, folder 16, Wiley, Roland (1977-1978), IREX Records.

${ }^{22}$ RC 075, folder 54, Spiegelman, Joel (1965-1966), IREX Records.

${ }^{23}$ RC 141, folder 35, Fay, Laurel (1975-1976), IREX Records.

${ }^{24}$ RC 227, folder 19, Taruskin, Richard (1971-1972), IREX Records.

${ }^{25}$ Richard Taruskin, On Russian Music (Berkeley: University of California Press, 2009), 6, https://doi.org/10.1525/california/9780520249790.001.0001.

${ }^{26}$ RC 124, folder 2, Carpenter, Ellon (1976-1977), IREX Records.

${ }^{27}$ RC 205, folder 16, Carlson, Marlan (1964-1965), IREX Records.

${ }^{28}$ Ibid.

${ }^{29}$ Ibid.

${ }^{30}$ Ibid.
} 
musicologists advising it functioned as gatekeepers not only in the US-Soviet exchange, but in the field of American musicology as well. Moreover, the underlying fear-on the part of the applicants and the selection committee-of choosing a topic that might prove to be unacceptable or offensive to the receiving side impacted the choice of research topics in equal measure. Thus, the exchange program was also shaped by the (perceived) ideological expectations of the Soviet Ministry of Culture and Soviet musicologists.

Students in music performance were not allowed to go to the Soviet Union under the auspices of the IUCTG. ${ }^{31}$ Following the sensational successes of Soviet virtuosi in the United States in the late 1950s, many graduate students at North American universities applied for the exchange program in order to study performance at world-famous conservatories in Moscow or Leningrad. All of them were rejected because, in the view of the selection committee, they were ineligible. While the reasons for denial were never articulated in official rejection notices, positivist ideals that placed a higher value on academic scholarship informed the thinking behind the exchange program. A sarcastic note on an application, reviewed by the program official David C. Munford, reads: "Not eligible. 'As a specialist he's a damn fine piano player' says the reference." ${ }^{32}$ In one case, the screening committee even called Paul Henry Lang at Columbia, who was not included in the applicant's list of references, "who confirmed our impression that [Igor] Buketoff is a performing musician rather than a productive scholar." 33 When advising on the application of the singer Ilana Mysior, Malcolm Brown wrote of "the old controversy of whether or not the Committee should support performers." ${ }^{34}$ Indeed, in the early 1960s at the suggestion from the Soviet side, the IUCTG considered initiating a program of individual exchange for conservatory instructors and other professional performers. The US side, however, was hesitant. In 1963, the deputy chairman of the program, Stephen Viederman, relayed his thoughts on the desirability of the performing exchange:

Dean Bain seemed to indicate that this would be primarily useful for purposes of 'mutual understanding, a phrase I rank with peaceful coexistence in terms of its being reasonably devoid of meaning. The American going over to instruct would bring a new repertoire with him, and would thus broaden Russian horizons. Personally, if he could stand the year and Soviet bureaucracy, he would gain little professionally, unless he was really able to sit down with some of their best people and exchange ideas, techniques, etc. The Soviet coming to the States would likewise bring a new repertoire, which would be useful. But if his English were not good, and he was not really one of their top flight people, there would be little to gain for the American student.... The Committee was somewhat dubious, for there seemed to be little benefit in this, other than the political, and we are not sure that the political can be achieved except as a direct by-product of something of artistic or educational valueefficiently, at least." 35

In Viederman's understanding, then, the political seemed to be a benefit distinct and separate from the aesthetic, albeit linked to it causally. His assessment of the Soviet educational system was also influenced by the unenthusiastic final reports of the students who went on exchange earlier, notably Stanley Krebs-a topic that I will take up in the penultimate section of this essay. However, the selection

\footnotetext{
${ }^{31}$ As opposed to, for instance, Fulbright grants.

${ }^{32}$ RC 067, folder 8, Nowak, Lionel (1958), IREX Records

${ }^{33}$ RC 224, folder 8, Buketoff, Igor (1956), IREX Records

${ }^{34}$ RC 066, folder 29, Mysior, Ilana (1964-1965), IREX Records.

${ }^{35}$ RC 091 Miscellaneous programs, music exchanges, state correspondence (1961-1963), IREX Records.
} 
committee followed a strict policy of not admitting performers ever since 1958 - the first year of the agreement — that is, since before they received the first reports from the Soviet Union. ${ }^{36}$

\section{Biopolitics}

That people who went on exchange to the Soviet Union were to function as "sources of unbiased information" about the American way of life meant that the applicants had to fit a rigid mold of "a model American citizen"-a category that was raced, gendered, and followed strict standards of sexuality, ability, and mental health. ${ }^{37}$ Thus, Cold War politics manifested through biopolitics.

The selection process was long and onerous-data sheets, research statements, personal statements, recommendation letters, budgets, interviews, language exams, and medical histories were mandatory. Historian Lewis Siegelbaum, applying to IREX in 1972, described the application form as having been "devised by sadistic bureaucrats." ${ }^{38}$ In addition to copious materials detailing their institutional position and research proposal, the applicants were required to submit a form filled out by their physician, certifying mental and physical health and detailing any possible health issues. In fact, the award of the fellowship was contingent on the fact that the recipient "must be in good health." 39 According to the chairman of the IUCTG Robert F. Byrnes, "the peculiar stresses and strains of living in the Soviet Union make it essential that we also give serious consideration to each applicant's physical and moral stamina, his emotional balance, his tact and tolerance, and his good judgement in dealing with difficult and unexpected situations." ${ }^{\prime 40}$ As early as question four in the official request for reference letters, the recommenders were asked: "How would you rate the applicant's political maturity and emotional stability? In these respects, do you consider him completely qualified for a year of life in the Soviet Union?" 41 Looking to give the best endorsement to the applicants, letter writers emphasized sound mental health and social adjustment: "Dr. Velimirovic is emotionally mature and stable; his home life is very happy. I know of nobody better adjusted than he is," wrote Albert Lord about Milos Velimirovic, an applicant for the senior scholar program. Assertions of pleasant personality and temperament were equally ubiquitous. A piano teacher at the Peabody Institute, Roberta Franke wrote about the applicant Thomas Baker: "Since he comes from a Quaker background and takes his religious heritage very seriously, he is especially well fitted temperamentally to do research in Russia and to meet his Russian fellow students tolerantly and with the desire to improve American relations with them. I am convinced that he would take his responsibility very seriously as a representative of his country and its highest ideals." ${ }^{42}$

The vague phrase "emotional stability," included in the reference form, invited broad interpretations. Some recommenders found it necessary to touch upon the applicant's sexuality. Since many people regarded homosexuality as a pathology, they felt that in response to a question asking about "emotional stability" of the applicants, they had to emphasize their status as straight men to ward off any

\footnotetext{
${ }^{36}$ RC 067, folder 8, Nowak, Lionel (1958), IREX Records.

${ }^{37}$ As evidenced by the application and selection process.

${ }^{38}$ Siegelbaum, Stuck on Communism, 49.

${ }^{39}$ RC 145, folder 18, Beckwith, Robert (1975-1976), IREX Records.

${ }^{40}$ RC 097, folder 18, Velimirovic, Milos (1965-1966), IREX Records.

${ }^{41}$ RC 218, folder 27, Brown, Malcolm H. (1961-1962), IREX Records.

${ }^{42}$ RC 216, folder 7, Baker, Thomas (1968-1969), IREX Records.
} 
suspicion-possibly keeping in mind the widespread stereotype that linked homosexuality and music. ${ }^{43}$ "Personable,-warm \& friendly, and genuinely interested in other people,—attractive physically,- and being the fortunate possessor of a really rugged physique, - there can be no doubts or hesitations concerning his attributes in these areas," ${ }^{44}$ wrote composer Robert Gross, chairman of the Music Department at Occidental College, of one applicant. "Rugged physique" as a euphemism for straightness was likely invoked to offset the previous phrase "attractive physically." A faculty member at the Eastman School of Music, Eugene J. Selhorst, wrote in a reference letter dated 1963: "Healthy in all respects-mentally, physically, sexually-(though probably not an angel) he has an excellent record of behavior." ${ }^{45}$ Thus, the writer affirmed the traditional ideal of masculinity, drawing attention to the applicant's straightness and sexual promiscuity at the same time. Such sentiment was exemplary of the homophobic culture at the Eastman School of Music that carried out gay purges in the 1930s and 1940s. ${ }^{46}$ Policing sexual behavior of students already in the Soviet Union also fell under the purview of IUCTG. As one participant recalled, "our briefers seemed to be preparing us for combat against a web of espionage and sexual seduction." ${ }^{27}$

Nevertheless, being "a model American citizen" or even having impeccable political credentials were not necessarily the decisive factors in the selection process. One case in which the strength of research proposal outweighed the negative impression the applicant made on the interviewers was the case of Richard Taruskin, then twenty-five years of age. Taruskin's interviewers were Holland Hunter, a professor of economics at Haverford College, and Vera Dunham, a professor in the Slavic Department at Wayne State University. Dunham's frustration with the interviewee was apparent from the start. Already in the first field of the form, "Appearance," she wrote: "Bearded snob." of the interview form titled "Personality: (Maturity, stability, sense of humor, ability to articulate, aggressiveness-submissiveness, self-confidence, shyness, etc.)," Hunter noted: "He looks down his nose at us in a most superior and languid way. "There is a great deal of historical misconception I hope to rectify." "49 The cover sheet of the interview report noted: "Special orientation re: family and Jewish situation." ${ }^{50}$ This was a reference to a relative in the Soviet Union, General Georgi Lieb who had headed the Moscow Synagogue, but by the time of the interview was already deceased. Regarding this matter, Hunter noted: "Doesn't understand how a problem might arise with a dissident S[oviet] friend. Would resist being a spokesman for the US, just as visiting S[oviet] musicians refused to defend USSR at time of Czech[oslovakian] invasion." 51 The interview was conducted on December 6, 1970, when the memory of the 1968 Soviet invasion of Czechoslovakia was still fresh. The parallel being drawn here could only have been Taruskin's opposition to the Vietnam war, especially since the seemingly gratuitous reference to the facial hair likely signaled Dunham's perception of her interviewee as a hippie. Despite leaving his interviewers irritated and certain of his oppositional political stance, Taruskin

\footnotetext{
${ }^{43}$ See Nadine Hubbs, The Queer Composition of America's Sound Gay Modernists, American Music, and National Identity (Berkeley: University of California Press, 2004), https://doi.org/10.1525/california/9780520241848.001.0001.

${ }^{44}$ RC 037, folder 17, Remeta, Daniel R. (1969-1970), IREX Records.

${ }^{45}$ RC 205, folder 16, Carlson, Marlan (1964-1965), IREX Records.

${ }^{46}$ Michael S. Sherry, Gay Artists in Modern American Culture an Imagined Conspiracy (Chapel Hill: University of North Carolina Press, 2007), 27. I am grateful to Gabrielle Cornish and Jen Wang for pointing out layers of meaning in these documents.

${ }^{47}$ Engerman, Know Your Enemy, 240.

${ }^{48}$ RC 227, folder 19, Taruskin, Richard (1971-1972), IREX Records.

49 Ibid.

${ }^{50}$ Ibid.

${ }^{51}$ Ibid.
} 
nevertheless was selected for the grant. Vera Dunham noted his "superior competence" and "passionate" commitment to his work. "Manner is infuriating but eventually he is very appealing" was Holland Hunter's conclusion.

Soviet contacts, and especially family ties, were seen by everybody involved as a serious problem. Another case in point was ethnomusicologist Mark Slobin's application for the 1967-68 fellowship. His wife Greta Nachteiler Slobin was a former Soviet citizen-a fact Slobin's files mention on no less than half a dozen different occasions. All reviewers agreed it was physically prohibitive for her to go back to the Soviet Union. Already at the first stage of selection one of the readers noted on his report under "Policy questions": "Very doubtful that wife should accompany." ${ }^{53}$ Before the interview, the program assistant Patricia Lambrecht warned Slobin: "Naturally, the question of your wife's former citizenship is of great interest to the Committee." ${ }^{54}$ Eventually, this became one of the main reasons why Slobin, who passed the selection with flying colors, canceled his trip. In the letter turning down the grant, he wrote: "the Committee's doubts about my wife's return to the Soviet Union confirmed and reinforced my own uneasiness, and I feel I should temporarily suspend a trip to the Soviet Union." ${ }^{\text {} 5}$

\section{Reports from the Soviet Union}

Aside from the prohibition on dating Soviet citizens, viewed by IUCTG as a security risk, the students seemed to be free to handle the challenges of navigating Soviet life on their own. The grant recipients were required to submit comprehensive interim and final reports about their stay in the Soviet Union. The nature of these reports as historical documents is ambiguous. They were neither memoirs, since they were written on the spot, nor diaries, since they were official documents. Some of them trod a thin line between mandated reportage and friendly correspondence. ${ }^{56}$ Nevertheless, these reports documented-in exceptional detail—daily comings and goings of the exchange students, as well their attitudes towards Soviet music and Soviet life. Mundane matters such as explaining the structure of institutions, advice on how to deal with red tape, locations of bookstores and cafes, and descriptions of student accommodations take up large portions of the reports, as the authors were tasked with demystifying Soviet daily life for the subsequent cohorts of exchange students.

Much sarcasm was spent on describing the living conditions, which by American standards were obviously suboptimal: "The conservatory stolovaia [canteen] is on the ground floor of korpus [building] 1. I do not recommend it because the smell is exceedingly pungent, though fatalities appear to be rare," wrote Malcolm Brown. ${ }^{57}$ Theodore Levin described the living conditions in the dormitories as "a permanent purgatory of screaming teenagers, interior décor reminiscent of a reformatory or insane asylum, ... squat toilets whose sanitary conditions could turn the stomach of even the most hardened traveler, . . . and a virtually complete lack of privacy. ${ }^{, 8}$

\footnotetext{
52 Ibid.

${ }^{53}$ Ibid.

${ }^{54}$ RC 014, folder 12, Slobin, Mark S. (1967-1968), IREX Records.

55 Ibid.

${ }^{56}$ These reports were most likely being sent through the US embassy channels. On the limitations of writing through the Soviet open post, see Fitzpatrick, A Spy in the Archives, 237, 252, and 323.

${ }^{57}$ RC 218, folder 27, Brown, Malcolm H. (1961-1962), IREX Records.

${ }^{58}$ RC 270, folder 14, Levin, Theodore (1977-1978), IREX Records.
} 
Exchange students were assigned advisors from the conservatory faculty. For instance, Robert Beckwith worked with Elena Orlova, whom he praised in his report as an accomplished musicologist; Laurel Fay worked with Lev Raaben, whom she described as helpful. Brown initially requested Yuri Keldïsh as his advisor, but eventually was assigned to Boris Yarustovskiy because Keldïsh was unavailable. Although personal relationships were often cordial, the reports give no indication that the distrust toward Soviet musicology has ever dissipated. Stanley Krebs described the state of the art in the field as follows:

The soviet musicologist has so long borne the main burden of the ideology that the high standards borrowed from German musicology ... have been lost. Quality of scholarship is very low and methods are all but forgotten. This situation is not lost on Soviet musicologists themselves and they are bitterly critical of their own work and of the circumstances which have lowered their standards. ... Although much of the burden of the Stalin era has been removed, they still chafe under the restrictions of severe nationalism in handling any musical subject. Soviet writing on music involves a dissipated, pompous vocabulary. Interesting, penetrating analysis of works, contemporary or traditional, of ideas, of aesthetics is smothered in banal jargon and meaningless generalities. ${ }^{59}$

Frustrated, Malcolm Brown, "gave up attendance at the 3 classes for which he had auditor privileges, for time in the library or archive was more valuable. ${ }^{60}$ After all, the main objective of the fellowship was to get acquainted with the primary sources, not secondary ones-an attitude that has persisted among the North American scholars until the present day.

Being pioneers in the Soviet-US exchange during its formative years was undoubtedly challenging to everybody. But students' individual experiences of and attitudes toward their host institutions and environments differed considerably. For example, this difference is evident in the passages, which on the surface might seem similar, from reports of students hosted by the Moscow Conservatory only a couple of years apart. The first one comes from Stanley Krebs:

Because of the rigidity of the training apparatus, because of long isolation from western ideas, especially in education, because of the nationalistic and introspective-romantic thinking about music, the whole musical atmosphere seems a bit unhealthy and stiff to a westerner... . There is little the young American composer can gain here which can't be gained by analysis of scores at home. The theory of the advantages of sharing other musical atmospheres and surroundings is hard to maintain in Moscow. The teaching tradition is doggedly 19th century European. ... The composing technique is based on piano improvisation in the style of RachmaninovGlazunov. Harmony is studied from an understandable Russian viewpoint focusing, finally, on the neo-romantic Russian tradition of the late 19th and early 20th centuries. ${ }^{61}$

The second one is from Malcom Brown:

Twice, now, I've heard concerts of new works by contemporary Soviet composers. ... What a pathetically bare musical culture! The quality of almost every work performed at these concerts suffered first from lack of basic craftsmanship and second from a sad "sameness" in creative imagination. ... Kabalevsky's sonata abounds in all the seventh-chord clichés of pop music; after several measures of percussive accompaniment in the extreme registers of the piano at one point, he apparently became so embarrassed that only a saccharine melody in the cello could redeem him from inclusion in the group of "reactionary atonalists." Even now, I

\footnotetext{
${ }^{59}$ RC 026, folder 14, Krebs, Stanley D. (1959-1960), IREX Records.

${ }^{60}$ RC 218, folder 27, Brown, Malcolm H. (1961-1962), IREX Records.

${ }^{61}$ RC 026, folder 14, Krebs, Stanley D. (1959-1960), IREX Records.
} 
can't be certain the whole piece isn't a hoax done with "tongue in cheek." Do they really believe the semantic slippage that brands Schoenberg, Hindemith, and much of Stravinsky as "reactionary," while calling Prokofiev's Seventh Symphony or Shostakovich's Twelfth, "progressive?"62

Both writers have similar aesthetic issues with Soviet composition: they consider it to be hopelessly outdated, compared to the high modernist aesthetic prevalent in the United States. However, while Krebs condemns what he sees as failings of the Soviet system, Brown tries to understand the thinking behind these failings. Although the former was a composer, and the latter a musicologist, this alone cannot account for the difference of approach: plenty of musicologists who followed in Brown's footsteps were less intent on understanding the internal logic of the Soviet art world.

Yet another approach to the perceived failings of the Soviet system was to try to rectify them. Echoing the official objective of the program to "promote within Soviet Russia an evolution" toward a better regime, Theodore Levin provided some advice on how exchange students could be helpful in educating Russian people about the United States:

Beyond a doubt, the very best way to get American materials into the hands of ordinary Soviet citizens who will use them and appreciate them is through exchange students. Each student develops a web of Soviet contacts, and with the propensity of Soviets to share coveted materials from the West with trusted friends, it is undeniable the most advantageous way to put these items into circulation, rather than resign them to the restricted zones of libraries or as official gifts to bureaucrats who will ensure that they never find their way to popular dispersal. ${ }^{63}$

Theodore Levin's fieldwork in Uzbekistan left him disappointed with the Soviet standardization practices that all but erased indigenous music cultures. Justifiably, he ranted against the "revoltingly ethnocentric pretense, bringing a measure of 'progress' to primitive and archaic local systems." 64 Admitting his exasperation-even though he accepted this state of affairs as a valid result of his fieldwork-he nevertheless reported that it was "possible, in fact, that the large numbers of conversations held with Uzbeks about what I felt to be the importance of reviving a truly nationalist basis of music theory (and therefore, musical thought), might bear results in the future." ${ }^{5}$

In the later years of the program, the pioneers of the IUCTG exchange went on to serve in an advisory capacity in the selection process. Composer Stanley Krebs and musicologist Malcolm Brown were the first two students to submit substantial reports about their experiences with the Soviet educational system and therefore to map this terra incognita for the State Department officials back in the United States. Upon completing his program, Krebs published an article "Soviet Music Instruction: Service to the State" on the education system in Russia. ${ }^{66}$ However, the article does not nearly approach the level of bitterness about having to waste his time at an institution he considered pitiable that was evident in his correspondence. Here is a representative fragment from his report:

Only idiocy would bring an American to Moscow to study voice. The vocal school was hardest hit by the earlier dogma that there was, indeed, a tradition of classic singing and vocal training

\footnotetext{
${ }^{62}$ RC 218, folder 27, Brown, Malcolm H. (1961-1962), IREX Records.

${ }^{63}$ RC 270, folder 14, Levin, Theodore (1977-1978), IREX Records.

${ }^{64}$ Ibid.

${ }^{65}$ Ibid.

${ }^{66}$ Stanley D. Krebs, “Soviet Music Instruction: Service to the State,” Fournal of Research in Music Education 9, no. 2 (1961): 83107, https://doi.org/10.2307/3344306.
} 
in Russia. The result is the almost unbearably bad, bull-like voices of the Bolshoi opera. And these are the teachers at the conservatory. The situation has become bad enough for the government to act. The writer understands that the state is undertaking to open a vocal exchange with Italy - the line now is “. . . we have the greatest raw material on earth, it's just not developed." The awareness of the need for foreign help is not accompanied by awareness of the diversity of western vocal style. They want their singers formed in the model of Mario del Monaco. They don't see or feel the differences among del Monaco, Schwarzkopf, and Peter Peers [sic], for instance. ${ }^{67}$

Instrumental performance, conducting, and composition also received their fair share of scathing criticism. Krebs's report established the baseline for what the IUCTG thought of the level of instruction at Russian conservatories. The chairman David Munford promptly shared the report with Mark Schubart, the dean of the Juilliard School of Music, appending a warning that Krebs "asks me kindly to protect him from indiscreet use of what he wrote for you and me." ${ }^{68}$ Indeed, the IUCTG's commitment to protect this valuable information from leaking into public access was evident from the edits to official correspondence. Just three months after Krebs's report came in, a draft of a rejection notice read as follows: "Recent information has indicated beyond any doubt that there is little or no value to be gained by an American wishing to study voice in the Soviet Union. The earlier traditions of singing have been hard hit by political changes within the conservatories." read: "Our limited experience raises some questions about the values to be gained by a Western student of voice in the music conservatories of the Soviet Union."70 Such protectionist attitude towards the reports from the Soviet Union, along with the value the State Department placed on this informationit informed future policies of the program, such as its stance on awarding grants to performers-is remarkable. Whether or not all students were cognizant or approving of such use of their correspondence, their reports were used as, plain and simple, reconnaissance work.

\section{Outcomes}

The point of view that the end of the Soviet Union was brought about by the subtle subterfuge of Western visitors who steadily exposed the Soviets to their values and views has outlived the Cold War. As late as 2003, Yale Richmond based his book Cultural Exchange and the Cold War on this premise. ${ }^{71}$ The IREX documents show that the attitude towards academic exchange as a display of soft power indeed informed the politicized ways in which American musicologists approached their Soviet colleagues. However, the streams of influence flowed in both directions.

No other report is so rich in descriptions of socializing with the Soviets as Malcolm Brown's. He seemed to be having the time of his life listening to jazz with his roommates at the Moscow Conservatory dorms and talking with random people he met on trips to provincial Russia. Consider this passage from his letter describing a conversation with a group of students he met on a trip to Yaroslavl', where he went, incidentally, in the same group with another would-be famous Russianist, Carl Proffer:

\footnotetext{
${ }^{67}$ RC 026, folder 14, Krebs, Stanley D. (1959-1960), IREX Records.

${ }^{68}$ RC 289, Colleges and universities, Juilliard School of Music (1959-1960), IREX Records.

${ }^{69}$ RC 009, folder 13, Miller, Donald (1960-1961), IREX Records.

${ }^{70}$ Ibid.

${ }^{71}$ Yale Richmond, Cultural Exchange and the Cold War: Raising the Iron Curtain (University Park: Pennsylvania State University Press, 2003).
} 
As always, the subject of music came up. I can't say how impressed I am with the Russian consciousness of their rich cultural heritage. Everyone knows the names and works of Pushkin, Tchaikovsky, Gogol, Turgenev, Musorgsky, Repin, etc., etc. These people in Yaroslavl have an immersive record collection-mostly vocal—that covers all kinds of music, from the most banal to the most exalted. From all I can see, when one loves music here, it means music of all kinds, without the boundaries of "pop, classics, jazz, or bop."72

In a rarely candid account of Soviet influence on a Western scholar's work, Sheila Fitzpatrick gives her close friend Igor Sats his due: “As far as my professional work on the Soviet Union is concerned, Igor's footprints are all over it, and will be forever. And I suppose . . . his footprints can be found in [my students'] work, albeit fainter and unrecognised by them."73

On a larger scale, as Danielle Fosler-Lussier writes, " $[t]$ he development of state-to-state exchanges helped build a world where peaceful coexistence could be imagined, for the process of resolving conflicts established routines for managing those conflicts." ${ }^{~} 74$ Furthermore, a common sentiment among the exchangees from any discipline was that the trip allowed them to draw "a wholly more differentiated map of the Soviet universe." 75 Describing every aspect of his life as an exchange student in Moscow, Brown wrote: "I have observed a greater freedom in conversation and greater license in public conduct than I ever expected in a police state."76 Similar sentiments of stereotypes dispelled, misconceptions overturned, and personal contacts established, echo in other musicologists' reports. ${ }^{77}$

Results of the American exposure to the Soviet music world would come to fruition during the 1980s and 1990s, when the former IREX exchange students went on to define the field of Russian music studies in the United States and put forth less othering, less Cold-War-molded approaches to Soviet music. The footprints of their Soviet friends and acquaintances could be found in their work, too.

\section{Bibliography:}

\section{Archives:}

International Research and Exchanges Board Records, Manuscript Division, Library of Congress, Washington, DC.

Central Decimal File 1955-59, Record Group 59, National Archives at College Park, Maryland.

\section{Sources cited:}

Engerman, David C. Know Your Enemy: The Rise and Fall of America's Soviet Experts. New York: Oxford University Press, 2009.

Fitzpatrick, Sheila. A Spy in the Archives: A Memoir of Cold War Russia. London: I. B. Tauris, 2015.

Fosler-Lussier, Danielle. Music in America's Cold War Diplomacy. Berkeley: University of California Press, 2015. https://doi.org/10.1525/california/9780520284135.001.0001.

\footnotetext{
${ }^{72}$ RC 218, folder 27, Brown, Malcolm H. (1961-1962), IREX Records.

${ }^{73}$ Fitzpatrick, $A$ Spy in the Archives, 330.

${ }^{74}$ Danielle Fosler-Lussier, Music in America's Cold War Diplomacy (Berkeley: University of California Press, 2015), 200, https://doi.org/10.1525/california/9780520284135.001.0001.

${ }^{75}$ Engerman, Know Your Enemy, 88.

${ }^{76}$ Ibid.

${ }^{77}$ As well as in later-day recollections of the students' stay in the Soviet Union. For example, see Richard Taruskin's Introduction to On Russian Music, 6.
} 
Frolova-Walker, Marina. “An Inclusive History for a Divided World?, Journal of the Royal Musical Association 143, no. 1 (2018): 1-20. https://doi.org/10.1080/02690403.2018.1434308.

Hubbs, Nadine. The Queer Composition of America's Sound: Gay Modernists, American Music, and National Identity. Berkeley: University of California Press, 2004. https://doi.org/10.1525/california/9780520241848.001.0001.

Krebs, Stanley D. Soviet Composers and the Development of Soviet Music. New York: W. W. Norton, 1970.

—. "Soviet Music Instruction: Service to the State." Journal of Research in Music Education 9, no. 2 (1961): 83-107. https://doi.org/10.2307/3344306.

Richmond, Yale. Cultural Exchange and the Cold War: Raising the Iron Curtain. University Park: Pennsylvania State University Press, 2003.

Saul, Norman E. "The Program that Shattered the Iron Curtain: The Lacy-Zarubin (EisenhowerKhrushchev) Agreement of January 1958." In New Perspectives on Russian-American Relations, edited by William Benton Whisenhunt and Norman E. Saul, 229-39. New York: Routledge, 2016. https://doi.org/10.4324/9781315689777-17.

Sherry, Michael S. Gay Artists in Modern American Culture an Imagined Conspiracy. Chapel Hill: University of North Carolina Press, 2007.

Siegelbaum, Lewis H. Stuck on Communism: Memoir of a Russian Historian. Ithaca, NY: Northern Illinois University Press, an imprint of Cornell University Press, 2019. https://doi.org/10.7591/9781501747397.

Taruskin, Richard. On Russian Music. University of California Press, 2009. https://doi.org/10.1525/california/9780520249790.001.0001. 